How to cite this article:

Gokce, S. G., Mengenci, C., Arslan, V., \& Emhan, A. (2019). The effects of emotional regulation and political perception on job satisfaction: An empirical research in the Turkish health sector. International Journal of Management Studies, 26(1), 55-71.

\title{
THE EFFECTS OF EMOTIONAL REGULATION AND POLITICAL PERCEPTION ON JOB SATISFACTION: AN EMPIRICAL RESEARCH STUDY IN THE TURKISH HEALTH SECTOR
}

\author{
SINEM GURAVSAR GOKCE \\ CENGIZ MENGENCI* \\ VAKKAS ARSLAN \\ ABDURRAHIM EMHAN \\ TED University, Ankara, Turkey \\ *Corresponding Author: cengizmengenci@yahoo.com
}

\begin{abstract}
This study aims to find out the relationship between emotion regulation, political perception and job satisfaction by using the Structural Equation Model and to examine whether demographic factors have an effect on this relationship. To test the model, other than the demographic variables, a 19question scale was applied to 699 employees in the health sector in Diyarbakur, which is located in the Eastern Anatolia Region of Turkey. To analyze the collected data, Structural Equation Modeling method was used with the aid of AMOS 18.0 software. A positive linear relationship between emotion regulation and job satisfaction and a negative relationship between political perception and job satisfaction were determined. Besides these two latent variables, emotion regulation and political perception; it was found that age, sector and title contributed to explain variances in the job satisfaction variable which was at $34 \%$. Additionally, some differences in terms of demographic variables were found. The job satisfaction of employees working in private hospitals was higher than those working in public hospitals; the emotion regulation ability of employees working in public hospitals was higher than those working in private hospitals; the emotion regulation ability of employees between the age 41 and 50 was higher than those who were younger; the emotion regulation ability of employees who had undergraduate degrees was higher than those who had graduate degrees.
\end{abstract}


Keywords: Emotion regulation, political perception, job satisfaction, structural equation model, health sector.

Received: 12/4/2019 Revised: 16/10/2019 Accepted:31/12/2019 Published: 31/1/2020

\section{Introduction}

The researchers in this study intended to find out how political perception, and emotion regulation influenced job satisfaction. Early studies have shown that job satisfaction increased or decreased due to emotion regulation and political perception (Spector, 1997; Ferris, Frink, Galang, Kacmar., \& Howard, 1996). Although measuring many concepts in social sciences is challenging; as emotion regulation is directly related to subjective perception, it is harder to set this concept on a scale. In spite of this difficulty, the number of researches on this subject has increased, as it has been determined that emotion regulation or management affects performance in decision-making (Fenton-O'Creevy, Nicholson., \& Willman, 2011) and also organizational performance (Moon \& Lord, 2006). Similar to emotion regulation, job satisfaction, is defined as the positive or negative feelings of employees towards their jobs (Spector, 1997), and is accepted as one of the key variables, that is closely related to life satisfaction, motivation and organizational performance (Bakır, 2009).

As emotion regulation affects job satisfaction, quality customer service and even the health of employees (Kim, Bhave., \& Glomb, 2013), thus the relationship between emotion regulation and job satisfaction is examined.

The perception created by emotions which are directed by behavior is much more important than the behavior itself for the politicization of the organizational environment. So harmonizing the behaviors and perceptions, understanding and researching these perceptions are vital for organizations (Chan, Rosen., \& Levy, 2009; Erkutlu \& Karacaoğlu, 2015; Hassan, Vina., \& Ithnin, 2017). Due to this need, the relationship between political perception and job satisfaction is also examined in this study.

This study aims to examine the concepts of emotion regulation, political perception and together with job satisfaction in the health sector. Although the concept of emotion regulation, political perception and 
job satisfaction were examined in different combinations in different sectors (Rahman, Akhter., \& Khan, 2017; Akçay \& Çoruk, 2012; Ferris et al., 1996; Thiel, Griffith., \& Connelly, 2013), it can be seen that these three concepts were not studied much in the health sector, concurrently. It is thought that information obtained from this study would be useful for managers and related academicians.

The following section focuses on a review of research concepts and theories associated with emotion regulation, job satisfaction, and political perception. Then, hypotheses are developed and studies by previous scholars are also discussed. Then, the research methodology applied in this study is explained. Next, the findings of this study are shown and explained. Finally, the last section is a discussion leading to the conclusion, which includes practical and theoretical contributions of the study as well as suggestions for future research.

\section{Literature Review}

In this section, emotion regulation, political perception, job satisfaction and the relationships between these three concepts are examined separately.

\section{Emotion Regulation}

Sometimes, workers have to ignore or even override their emotions to cope well with the environment in challenging situations. In literature, it is called emotion regulation.

Wagstaff and Hanton (2013: 477) defined emotion regulation as being 'capable of keeping emotions under sufficient control to allow for interpersonal relatedness and sociability, prosocial initiatives when appropriate, sympathy toward others, personal assertiveness when needed, and/or other indices of successful functioning'.

Some of the literature in emotion regulation seek effective emotion management strategies (Thiel et al., 2013; Akçay and Çoruk, 2012) suggested approaches to effective emotion regulation; Lively and Weed (2014) explained sociological insights into what is emotion management; Wagstaff et al. (2013) aimed to improve the practice of individuals by providing an intervention to develop emotional abilities 
and strategies; Purnamaningsih (2017) and Turliuc and Bujor (2013) examined determinants and consequences of emotional management and Berking et al. (2010) focused on the possibility of emotion management as a skill which can be enhanced by training. Improving emotion management ability is important because otherwise emotion dysregulation will lead to hopelessness, dissatisfaction, hypertension, coronary heart disease; even accelerate cancer progression and failure correspondingly (Gross, 1989; Pennebaker, 1990; Walumbwa et al., 2010; Vatan et al., 2014).

Hochschild (1983), who is one of the pioneers in the study on emotion regulation, suggested mainly two strategies for employees to regulate their emotional displays: surface acting and deep acting. Surface acting means managing the expressions by hiding an undesired emotion and deep acting refers to changing the felt emotion (Lively \& Weed, 2014; Diefendorff et al., 2008). In short, surface acting can be defined as the change in external expressions while deep acting is changing the internal feelings (Kim et al., 2013). The selection of these two strategies defines the effect of emotion regulation on job satisfaction, political behavior, quality customer service and even the health of employees.

\section{Political Perception}

Organizations are dynamic structures that have to host informal communities besides formal ones to continue its existence. Employees in these informal communities are almost always in a power struggle to maximize their profits and develop political behavior to win this struggle by affecting the behavior of other employees, turning the facts and status to their own advantage (K1rel, 1998).

The intention of an employee is the measure of deciding whether a behavior is political or not. The measure of an employee's behavior that is going to be defined as political is his/her intention. If an employee behaves to ensure benefit to herself/himself, it means that this individual is behaving politically (Erol, 2015). Wickenberg and Kylen (2004) list the reasons for political behavior as the lack of clear goals, scarce resources, technological or environmental changes, nonscheduled decisions or organizational changes. All of these items point out the uncertainty that causes conflict of interest. As there is uncertainty in every organization, we can conclude that there is also political behavior in all organizations. 
Political behavior is important since it affects the methods and criteria of decision-making, the method and reason of how employees gain the support of others, how subordinates are motivated and the success level of implementation of organizational strategies, etc. Some sources define political behavior as behaviors that only serve an individual and are not approved by the organization, and some others claim that it may have positive outcomes as well by defining it as a social affecting process to implement benefits (Demirtaş, 2013). Whether its results are positive or negative, an objective political behavior is evaluated by subjective political perceptions (Bursalı \& Bağcl, 2011). This subjectivity might cause different understandings of the same situation by different people. That is why political perceptions are accepted as more important than the behavior because the perception of political environment is closely related to how a behavior and emotions caused by that behavior is perceived by others. Political perception leads employees to perceive the environment as political even if there is no political behavior in reality (Bursalı \& Bağcl, 2011). The negative or positive perception of a political environment affects the reactions of employees, right down to their managers, colleagues and organizations as a whole besides their expectations, performance, and work-related results (Ferris et al., 1996).

\section{Job Satisfaction}

In previous studies (Porter, 1962; Lock, 1969), job satisfaction was defined as the mood of employees in an organization that can be gained by meeting the physical and psychological needs of these employees (Porter, 1962). In subsequent studies, researchers (Singh \& Rhodes, 1994) focused on the perceptions of employees and job satisfaction was defined as the feelings of employees towards their jobs and the status of liking or disliking their jobs (Spector, 1997).

According to Kooij, Jansen, Dikkers, and De Lange (2009), the job satisfaction level of employees is defined by an emotional status that is formed by the evaluation of the employees' job experience or the level of satisfaction due to the effective involvement of the employees in the organization. On the other hand, Poyraz and Kama (2008) claimed that job satisfaction is related to the needs and expectations of employees.

Studies on the job satisfaction level of employees and the factors affecting this level showed different results. According to Sasse (1981) 
(as cited in Günbay1, 2000) and Rosli and Wahab (2013) these factors are: the nature of the work, promotion opportunities, relationship among employees at the workplace, salary and prestige. On the other hand, according to Droussiotis (2004) these factors are: working conditions, physical conditions of the workplace, rewards that can be obtained at the end of work, behavior of colleagues and the difficulty or attractiveness of the job. Price and Muller claimed that communication among colleagues and discretion on work done are important factors for job satisfaction (Demirhan, Kula., \& Karagoz 2014). In Turkey, these factors are listed as: working conditions, wages, the nature of the job, management policies and colleagues (Serinkan \& Bardakçı, 2007). In another study, these factors were grouped into five as: environmental factors (social, familial and economic reasons, etc.), organizational factors (nature of the business, wages, promotion, etc.), cultural factors (beliefs, values and judgment, etc.), individual factors (promotion, desire, etc.) and work environment factors (administrative support, colleagues, etc.) (Rahman et al., 2017).

Although classifications and detailed levels are different, it can be concluded that job satisfaction is mainly related to an individual's characteristics, the nature of the job, career opportunities, financial opportunities, physical and social work environment and other environmental related factors.

\section{Relationship between Emotion Regulation, Political Perception and Job Satisfaction}

The latest studies on emotion regulation states that this ability affects job satisfaction, quality customer service and even the health of employees (Kim et al., 2013). Job satisfaction, contrary to common belief, is related not only to materiality but also to environmental, cultural, individual and organizational spheres. There it can be said that emotions and perceptions play a major role in the job satisfaction of employees. In this study, a positive relationship between emotion regulation and satisfaction is examined.

As some strategies of emotion regulation, namely "surface acting strategy", which is defined as regulating the expression of emotion rather than the emotion itself, are based on the same objectives of political perception like acting politically in accordance with the expectations of employees: so as not to lose his/her job, to gain awards, or to avoid penalties. On the other hand, according to Hochschild 
(1983) another emotion regulation strategy is deep acting in which emotion is forced to change according to environmental expectations. When this occurs, stress is accumulated by a person, and that could reduce job satisfaction (Kooij et al., 2009). It has been evaluated that if emotion regulation has a relationship with job satisfaction, then political perception could also be related to satisfaction.

The criteria of reward and promotion in organizations that have high political perception will depend on subjective and unfair factors (Chan et al., 2009; Hassan et al., 2017). Consequently, employees who do not believe that they will get what they deserve will have a low level of motivation, morale, trust, psychological well-being and job satisfaction (Erkutlu \& Karacaoğlu, 2015). Therefore, it is expected that as political perception increases, job satisfaction will decrease.

The following hypotheses based on the theoretical framework of the study are formulated:

$\mathrm{H}_{1}$ : There is a positive relationship between emotion regulation and job satisfaction.

$\mathrm{H}_{2}$ : There is a negative relationship between political perception and job satisfaction.

$\mathrm{H}_{3}$ : Emotion regulation and political perception have significant effects on job satisfaction.

\section{Research Methodology}

\section{The Universe and Sample of the Research}

A questionnaire consisting of 19 questions, besides demographic variables was used to test the model. By using a stratified random sampling method, the questionnaires were administered to 710 healthcare employees in both public and private hospitals located in Diyarbakır, South-Eastern Region of Turkey. A total of 11 questionnaires were unanswered; therefore, 699 valid questionnaires were used for the analysis.

\section{Survey Instrument}

Demographic Information: This part of the questionnaire elicited the following information from the respondents. They include: age, 
gender, education level, marital status, work experience, department and position/title.

In addition to the demographic variables, three scales were used to define the emotion regulation, political perception and job satisfaction levels of the employees. They are as follows:

Emotion Regulation Scale: This scale was developed by Mulki et al. (2014) and consists of 4 questions with a 5-point Likert Scale (1-Absolutely don't agree, 2- Don't agree, 3- Partially agree, 4- Agree, and 5- Absolutely agree). The Cronbach's Alpha coefficient of the scale was found to be 0.86 . Skewness and Kurtosis values were between $-/+1$. Therefore its distribution is normal.

Job Satisfaction Scale: This scale was developed by Spector (1997) and adapted to Turkish version by Kula (2011). The scale consists of 9 questions with a 5-point Likert Scale (1-Absolutely don't agree, 2Don't agree, 3- Partially agree, 4- Agree, and 5- Absolutely agree). The Cronbach's Alpha coefficient of the scale was found to be 0.83 . Skewness and Kurtosis values were between $-/+1$. Therefore its distribution is normal.

Perception of Politics Scale (POPS): This scale was developed by Kacmar and Carlson (1997) and adapted to Turkish version by Demirtaş (2013) and consists of 6 questions with a 5-point Likert Scale (1-Absolutely don't agree, 2- Don't agree, 3- Partially agree, 4- Agree, and 5Absolutely agree). The Cronbach's Alpha coefficient of the scale was found to be 0.82 . Skewness and Kurtosis values were between $-/+1$. Therefore its distribution is normal.

\section{Data Analysis}

SPSS 18.0 software was used to analyze the data collected and AMOS 18.0 software for Structural Equation Modeling (SEM). SEM is a method that has the ability to analyze many variables at the same time (Wan, 2002) and that measurement errors are taken into account (Byrne, 2006). For SEM, different parameters are used in the literature for goodness-to-fit. Although there is no agreement on which parameter to use, it is recommended that several parameters should be used together. In this case, at least one parameter from each 
IJMS 26 (1), 55-71 (2019)

three fit test groups should be used (Garson, 2009). The most common fit statistics values are as follows: $\chi^{2}-p-\chi^{2} / d f$, RMSEA-PCLOSE, TLICFI and HOLTER Index (Uryan, 2010, p. 70-73). In this study, the significance level was accepted at $p<0.5$.

\section{Results}

The demographic structure of the employees who responded to the questionnaire is shown in Table 1.

Table 1

Demographic Variables

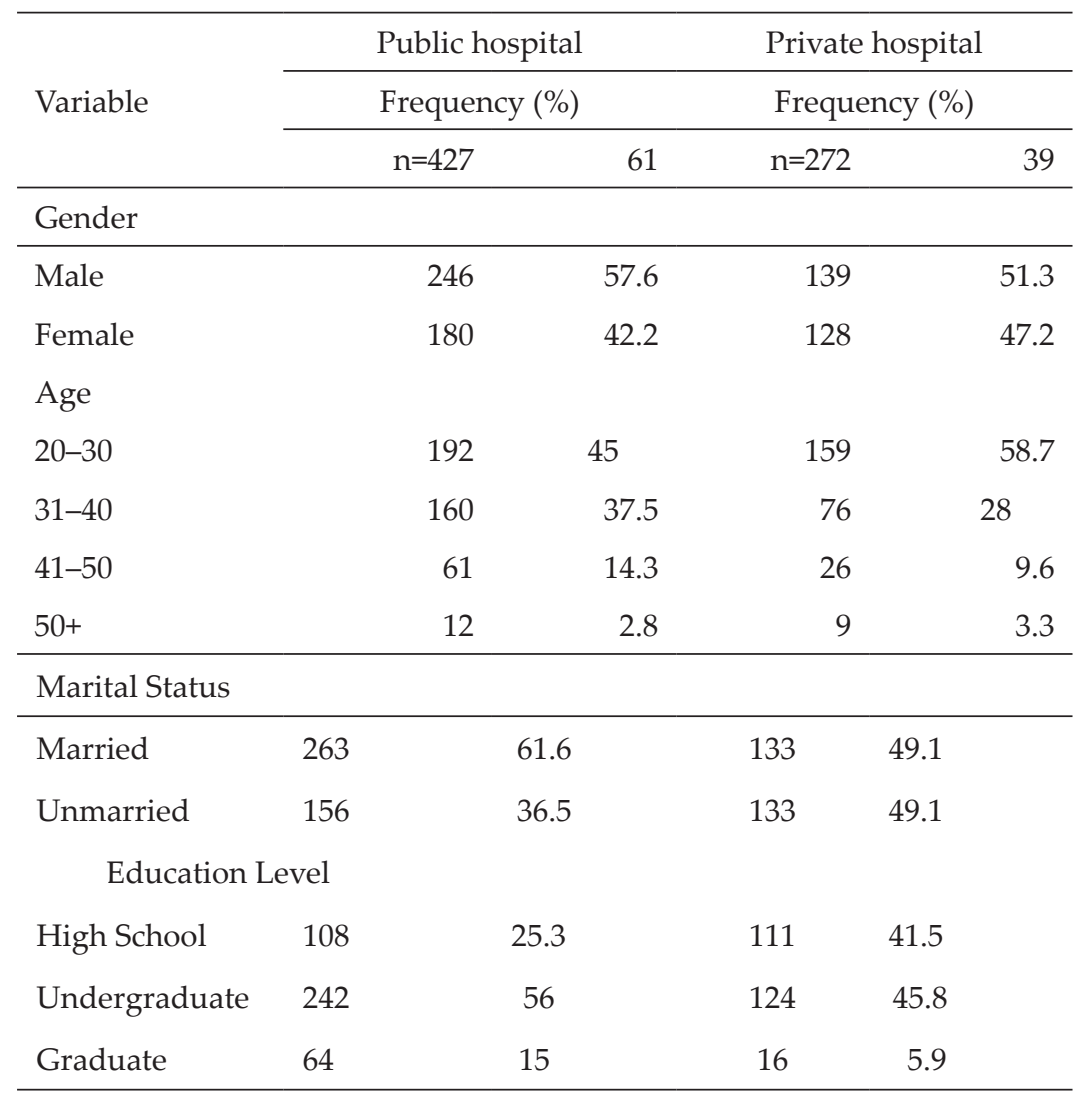

(continued) 
IJMS 26 (1), 55-71 (2019)

\begin{tabular}{lcccr}
\hline \multirow{2}{*}{ Variable } & \multicolumn{2}{c}{ Public Hospital } & \multicolumn{2}{c}{ Private Hospital } \\
\cline { 2 - 5 } & \multicolumn{2}{c}{ Frequency (\%) } & \multicolumn{2}{c}{ Frequency (\%) } \\
\cline { 2 - 5 } & $\mathrm{n}=427$ & 61 & $\mathrm{n}=272$ & 39 \\
\hline Experience (years) & & & & \\
\hline $1-5$ & 168 & 39.3 & 134 & 49.4 \\
$6-10$ & 103 & 24.1 & 70 & 25.8 \\
$11-15$ & 67 & 15.7 & 21 & 7.7 \\
$16-20$ & 34 & 8 & 15 & 5.5 \\
$20+$ & 41 & 9.6 & 15 & 5.5 \\
\hline Title & & & & \\
\hline Doctor & 90 & 21.1 & 16 & 5.9 \\
Nurse & 135 & 31.6 & 126 & 46.5 \\
Technician & 56 & 13.1 & 34 & 12.5 \\
Officer & 32 & 7.5 & 31 & 11.4 \\
Others & 103 & 21.1 & 59 & 21.8 \\
\hline
\end{tabular}

$\mathrm{n}=699$

61 percent of the respondents were from public hospitals and 39 percent were from private hospitals. There was a balance between male and female respondents and most of the respondents were below the age of 40 , married, had 1-5 years of experience and graduated from university.

The structural equation model of the relationship between the variables is given in Figure 1 as follows.

According to the revised SEM, the latent variables were connected to all indicators and the relationship between emotion regulation, political perception, and job satisfaction were statistically significant $(p<0.5)$. In this scope, the standardized regression weight of the relationship between emotion regulation and job satisfaction was 0.45 , and the relationship between political perception and job satisfaction was -0.18 . Based on this model, all hypotheses were supported. 


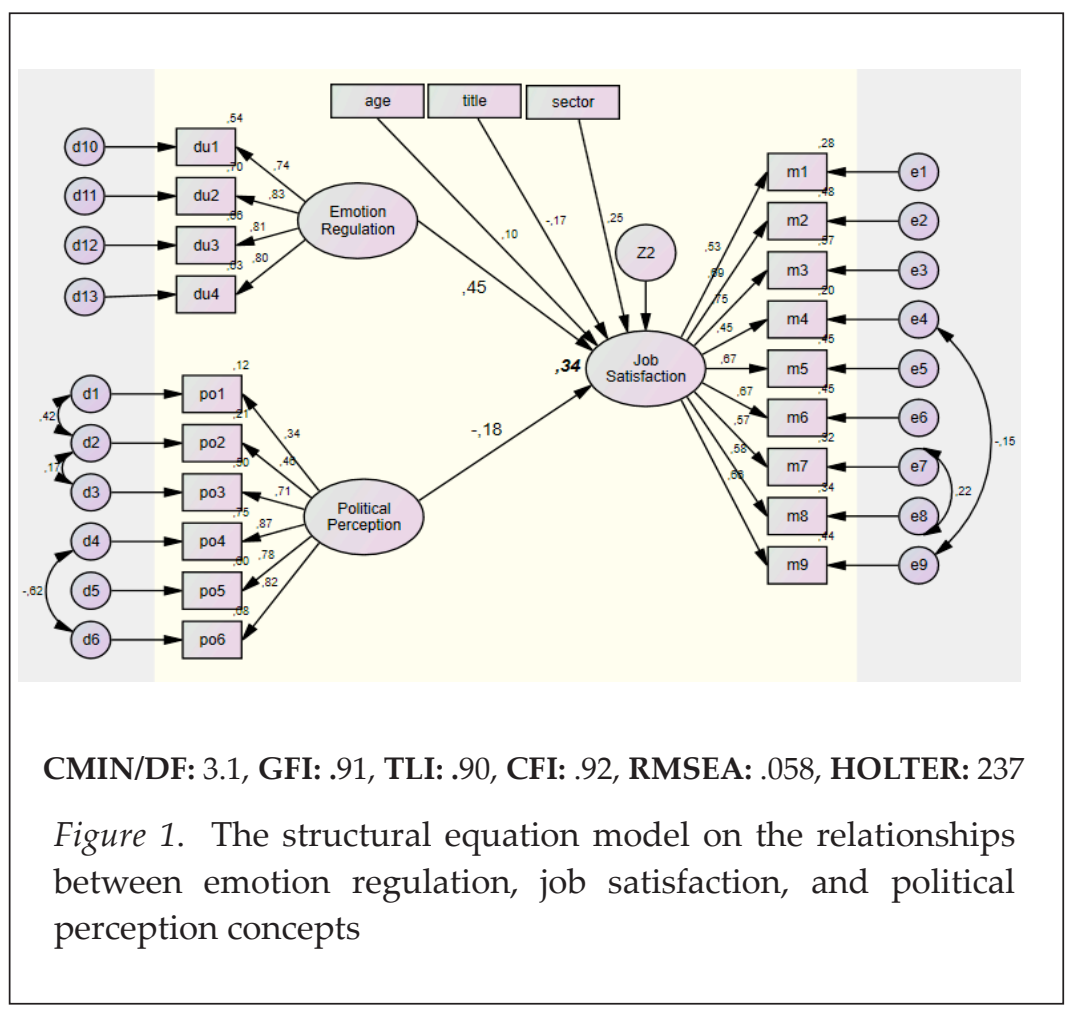

As a result, it was found that emotion regulation, political perception, age, title and working sector explained 34 percent of the variance in the job satisfaction variable. So the unexplained value $\left(Z_{1}\right)$ is 66 percent.

The results for some demographic variables are as follows:

- The job satisfaction of the employees working in private hospitals was higher than those in public hospitals ( $\mathrm{t}:-4.12$, $\mathrm{p}<0.001)$.

- $\quad$ The emotion regulation ability of the employees working in public hospitals was higher than those in private hospitals (t: $-3.53, \mathrm{p}<0.001)$.

- The emotion regulation ability of the employees between age 41-50 was higher than the younger ones (F: 2.67, p<0.05).

- The job satisfaction of the employees with 16-20 years of work experience was the highest ( $F: 3.73, \mathrm{p}<0.05)$. 
- The emotion regulation ability of the employees with undergraduate degrees was higher than those with graduate degrees (F: 3.272, p<0.05).

\section{Discussion and Conclusion}

Based on the results of the research, there was a positive linear relationship between emotion regulation and job satisfaction and a negative linear relationship between political perception and job satisfaction. Besides the two latent variables, emotion regulation and political perception; it was found that age, sector and title also contributed to explain the variances in job satisfaction variable which was found to be at 34 percent.

According to these findings, as the ability of emotion regulation of employees increased, their job satisfaction also increased. This result is consistent with studies which determined positive relationships between these two variables (Gürel \& Bozkurt, 2015). Therefore training programs that help healthcare employees to develop their emotion regulation abilities and apply effective regulation strategies are recommended to improve their level of job satisfaction.

When the negative relationship between political perception and job satisfaction was considered, it was found that the negative perception of the political environment in an organization can result in cynical behavior and employees with cynical behavior would believe that their organization was unfair and insincere (Demirtaş, 2013). This belief would negatively affect the social work environment, and in turn would also affect job satisfaction, negatively. Thus managers should avoid policies that encourage only surface acting strategies, which could result in forming political perception in the long term and affect job satisfaction negatively. In addition to this, managers should apply restrictions on unethical political behavior to avoid the negative effects of political perception. In addition to these results, the statistically meaningful differences of these variables based on the demographic variables were examined to come up with some suggestions for practitioners. For example, there were many studies in the related literature which claimed that career, job experience and age had an indirect, positive effect on emotion regulation $(\mathrm{Wu}, 2011$; Yozgat et al., 2013). Hence, consistent with these studies, we found 
that employees between the ages of $41-50$ have a higher ability in emotion regulation as compared to younger employees.

There are also many studies claiming that job satisfaction increases with age and experience since integration and harmony are increased by these variables as well (Clark, 1996; Malik at al., 2014). On the other hand, some studies found a U-shaped relationship between job satisfaction and age of employees (Gazioglu \& Tansel, 2006). Younger or older employees are more satisfied with their jobs. Malik et al. (2014) found that there is a correlation between age and job satisfaction. They confirmed that the older a worker, the lower his/her job satisfaction. This is because older workers lose their ambition, and feel that their work is boring and less interesting. But for younger workers, job is the center of their lives as they are more career-oriented. So it can be concluded that young and inexperienced employees have a lower level of satisfaction due to their higher expectations (Kara, 2010). Consistent with these studies, we have also found that employees with 16-20 years of experience have a higher job satisfaction level. Therefore, organizations should correctly inform their young and inexperienced employees about their job scope and opportunities available to avoid high expectations, which could decrease their job satisfaction in the long term. Another finding is that the job satisfaction level of employees working in private hospitals is higher than those working in public hospitals. In fact, there are inconsistent and indefinite results in studies comparing job satisfaction between the public and private sector in the literature. Some studies found that private sector workers are more satisfied than public sector workers (Kovach, 1990), while, some studies confirmed that private sector workers are less satisfied than public sector workers (Smith et al., 1980). On the other hand, some studies showed that there is no difference between the public and private sector (Cho \& Lee, 2001). In this study, the results showed that private sector workers have higher job satisfaction. This result can be explained by way of the bureaucratic structure, routine work, limited career opportunities and limited economic opportunities in the public sector. In addition to this, the policies of the private sector on wages, reward and promotion influence job satisfaction positively. Thus, the satisfaction levels of public sector employees could be improved by defining more effective rewards and promotion criteria rather than ones that decrease service quality like the number of patients.

The emotion regulation ability of employees working in public hospitals is higher than the ones working in private hospitals. 
Actually, the reverse may be expected since there is an obligation of emotion regulation for private sector employees due to the importance of patient satisfaction for profit requirement, but in the health sector, in which both the negative and positive effects of emotion regulation are observed dominantly, this requirement forces employees into surface acting. Results of some studies in the literature supported the findings obtained in this study. On the other hand, findings in some other studies showed the opposite (Oral \& Köse, 2011; Seçer \& Tinar, 2004). Oral and Köse's (2011) studies showed that public sector workers use surface action strategies and emotion regulation efforts more than those in the private sector. On the other hand, Seçer and Tinar (2004) found in their study that emotion regulation usage by the private sector was more than the public sector. Here, surface acting is defined as regulating the expression of the emotion rather than the emotion itself. This kind of acting causes stress as claimed by Cote and Morgan (2002) and refrained employees from deep-acting, which refers to the regulation of an emotion itself. Hence, this result might be explained by surface-acting and correspondingly high levels of stress in employees working in private hospitals due to profit requirement.

In evaluating the findings and discussion of this study, limitations of the study should also be taken into account. The study was limited to a single city in Turkey and only a limited number of questionnaires were administered. In addition, the study was based on the perception of employees rather than objective criteria as the case for all field studies using the questionnaire method. Nevertheless since the variables are also subjective concepts, this method is still the most valid one.

\section{References}

Akçay, C., \& Çoruk, A. (2012). Emotions in professional life and its management: A conceptual study (Çalişma yaşamında duygular ve yönetimi: Kavramsal bir inceleme). Eğitimde Politika Analizi Dergisi, 1(1), 3-25.

Bakır, E. (2009). The impact of demographic variables on the factors affecting job satisfaction and an application in the T. C. Ziraat Bank. Unpublished Master's Dissertation, Kocaeli University Institute of Social Sciences. Kocaeli, Turkey.

Berking, M., Meier, C., \& Wupperman, P. (2010). Enhancing emotionregulation skills in police officers: Results of a pilot controlled study. Behavior Therapy, 41, 329-339. 
Bursalı, Y. M., \& Bağcl, Z. (2011). Interrelations between political behavior and organizational politics perceptions of employees. Pamukkale University, Journal of Institute of Social Sciences, 9, 2341.

Byrne, B. (2006). Structural equation modeling with EQS: Basic concepts, applications, and programming. Mahwah, New Jersey: Lawrence Erlbaum Associates.

Chan, C., Rosen, C., \& Levy, P. (2009). The relationship between perceptions of organizational politics and employee attitudes, strain, and behavior: A meta-analytic examination. Academy of Management, 524, 779-801.

Cho, K-H., \& Lee, S-H. (2001). Another look at public-private distinction and organizational commitment: A cultural explanation. International Journal of Organizational Analysis, 9(1), 84-102.

Clark, E. A. (1996). Job satisfaction in Britain. British Journal of Industrial Relations, 34(2), 189-217.

Cote, S., \& Morgan, L. M. (2002). A longitudinal analysis of the association between emotion regulation, job satisfaction, and intentions to quit. Journal of Organizational Behavior, 238, 947962.

Demirhan, Y., Kula, S., \& Karagöz, G. (2014). The effect of job satisfaction and supervisor support on performance: The example of special operations police unit of Diyarbakir province. Süleyman Demirel University Faculty of Economics and Administrative Sciences Journal. 191, 285-297.

Demirtaş, Ö. (2013). Ethical leadership behavior impacts on perceived ethical climate: The mediating role of perceived organizational political. Erciyes University Institute of Social Sciences. Unpublished Dissertation, Kayseri, Turkey.

Diefendorff, J. M., Richard, E. M., \& Yang, J. (2008). Linking emotion regulation strategies to affective events and negative emotions at work. Journal of Vocational Behavior. 73, 498-508.

Droussiotis, A. (2004). The profile of high performing employees in Cyprus. Journal of Business in Developing Nations, 8, 39-64.

Erkutlu, H. V., \& Karacaoğlu, K. (2015). Regulatory impact of employee's political competence in the relationship between perceived organizational policy and worker alienation. Paper presented at the annual meeting at $23^{\text {nd }}$ National Management and Organization Congress, Muğla, Turkey.

Erol, E. (2015). Perceptions of organizational politics scale POPS questionnaire into Turkish: A validity and reliability study. International Journal of Assessment Tools in Education, 21, 58-78. 
Fenton-O'Creevy, M., Nicholson, S. E., \& Willman, P. (2011). Thinking, feeling and deciding: The influence of emotions on the decision making and performance of traders. Journal of Organizational Behavior, 328, 1044-1061.

Ferris, G., Frink, D., Galang, M., Kacmar, J., \& Howard, K. (1996). Perceptions of organizational politics: Prediction, stress-related implications and outcomes. Human Relation, 492, 233-266.

Garson, G. (2009). Structural equation modeling. Retrieved from http:// faculty.chass.ncsu.edu/ garson/PA765/structur.htm. Access date: 24.12.2018.

Gazioglu, S., \& Tansel, A. (2006). Job satisfaction in Britain: Individual and job related factors. Applied Economics, 38, 1163-1171.

Gross, J. (1989). Emotional expression in cancer onset and progression. Social Science and Medicine, 28, 1239-1248.

Günbayı, İ. (2000). Job satisfaction and motivation in organizations (Örgütlerde İş Doyumu ve Güdüleme). Özen Publishing, Ankara, Turkey.

Gürel, E. B., \& Bozkurt, Ö. Ç. (2015). Effects of emotion management on job satisfaction and levels of emotional burnout. Paper presented at the annual meeting at $23^{\text {nd }}$ National Management and Organization Congress, Muğla, Turkey.

Hassan, H., Vina, T. M. H., \& Ithnin, N. S. (2017). Perceived organizational politics and job satisfaction: The role of personality as moderator. LogForum 13(4), 479-493, http:// dx.doi.org/10.17270/J.LOG.2017.4.8

Hochschild, A. R. (1983). The managed heart: Commercialization of human feeling. Berkeley: University of California Press.

Kacmar, K. M., \& Carlson, D. S. (1997). Further validation of perceptions of politics scale (POPS): A multi sample investigation. Journal of Management, 23(5), 627-658.

Kara, N. (2010). Research the impact of role ambiguity and role conflict on the job satisfaction of workers. Marmara University, Institute of Social Sciences (Unpublished Master's Dissertation). Istanbul, Turkey.

Kim, E., Bhave, D. P., \& Glomb, T. M. (2013). Emotion regulation in workgroups: The roles of demographic diversity and relational work context. Personnel Psychology, 663, 613-644.

Kırel, Ç. (1998). Use of power in the organizations, an application on perceived power and responses of employees. Eskişehir, Turkey: Anadolu University Publications. 
Kooij, D. T. A., Jansen, P. G. W., Dikkers, J. S. E., \& De Lange, A. H. (2009). The influence of age on the associations between HR practices and both affective commitment and job satisfaction: A meta-analysis. Journal of Organizational Behavior, 318, 1111-1136.

Kovach, K. A. (1990). Comparisons of public and private subjects on reported economic measures and on facet satisfaction items for each of three organizational levels. Journal of Collective Negotiations, 19(4), 261-273.

Kula, S. (2011). Occupational stress and work-related wellbeing of Turkish national police TNP members (Unpublished Master's Dissertation). University of Central Florida, Orlando.

Lively, K. J., \& Weed, E. A. (2014). Emotion management: Sociological insight into what, how, why, and to what end? Emotion Review, 63, 202-207.

Locke, E. A. (1969). What is job satisfaction? Organizational Behavior and Human Performance, 4(4), 309-336.

Malik, M., \& Danish, R. (2009). Relationship between age, perceptions of organizational politics and job satisfaction. Journal of Behavioral Sciences, 19, 23-40.

Moon, S. M., \& Lord, R. G. (2006). Individual differences in automatic and controlled regulation of emotion and task performance. Human Performance, 194, 327-356.

Mulki, J., Jaramillo, F., Goad, E., \& Pesquera, M. (2014). Regulation of emotions, interpersonal conflict, and job performance for salespeople. Journal of Business Research, 683, 623-630.

Newman, A., Ucbasaran, D., Zhu, F., \& Hirst, G. (2014). Psychological capital: A review and synthesis. Journal of Organizational Behavior, 351, 120-138.

Oral, L., \& Köse, S. (2011). A study on the relationship between emotional labor utilization of physician, job satisfaction and burnout levels. Süleyman Demirel University, Faculty of Economics and Administrative Sciences Journal, 162, 463-492.

Pennebaker, J. (1990). Opening up: The healing powers of confiding in others. New York: William Morrow.

Porter, L. (1962). Job attitudes in management: I. perceived deficiencies in need fulfillment as a function of job level. Journal of Applied Psychology, 466, 375-384.

Poyraz, K., \& Kama, B. (2008). A study of the effect on job satisfaction of perceived job security, organizational commitment and intention to leave work. Süleyman Demirel University Journal of Economics and Administrative Sciences, 132, 143-164. 
Purnamaningsih, E. H. (2017). Personality an emotion regulation strategies. International Journal of Psychological Research, 10(1), 53-60.

Seçer, Ş., \& Tinar, M. Y. (2004). Emotional labor as a source of burnout at work: A research on nurses (iş yerinde tükenmişlik kaynaği olarak duygusal emek: Hemşireler üzerinde yapilan bir araştirma). 9nd Ulusal Ergonomi Kongresi Bildireler, Pamukkale University, Denizli.

Serinkan, C., \& Bardakçı, A. (2007). A research on job satisfaction of teaching staff in the Pamukkale university. Karaman Journal of Economics and Administrative Sciences 12, 152-163.

Singh, J., \& Rhodes, G. (1994). Boundary role ambiguity in marketing oriented positions: A multidimensional multifaceted operationalization. Journal of Marketing Research, 31, 328-338.

Smith, M. P., \& Nock, S. L. (1980), op. cit.; DeSantis, V. S., \& Durst, S. L. (1996). Comparing job satisfaction among public and privatesector employees. American Review of Public Administration, 26(3), 327-343.

Spector, P. (1997). Job satisfaction: Application, assessment, causes, and consequences. California: Sage Publications.

Rahman, K., Akhter, W., \& Khan S. U. (2017). Factor affecting employee job satisfaction: A comparative study of conventional and Islamic insurance. Cogent Business \& Management, 4(1), 1273082.

Rosli, R., \& N. Ab., Wahab (2013). Roles of job satisfaction in ensuring quality of working life. International Journal of Management Studies, 20(2), (129-144) (2013).

Thiel, C., Griffith, J., \& Connelly, S. (2013). Leader-follower interpersonal emotion management: Managing stress by person-focused and emotion-focused emotion management. Journal of Leadership \& Organizational Studies, 22(1), 5-20.

Turliuc, M. N., \& Bujor, L. (2013). Emotion regulation between determinants and consequences. Procedia - Social and Behavioral Sciences, 76, 848-852.

Uryan, Y. (2010). Organizational safety culture and individual safety behavior: A case study of the Turkish national police aviation department (Unpublished Master's Dissertation). University of Central Florida, Orlando.

Vatan, S., Lester, D., \& Gunn, J. F. (2014). Emotion dysregulation, problem-solving, and hopelessness. Psychological Reports, 1142, 647-651. 
Wagstaff, C. R., \& Sheldon Hanton, D. F. (2013). Developing emotion abilities and regulation strategies in a sport organization: An action research intervention. Psychology of Sport and Exercise, 14, 476-487.

Walumbwa, F. O., Peterson, S. J., Avolio, B. J., \& Hartnell, C. A. (2010). An investigation of the relationships among leader and follower psychological capital, service climate, and job performance. Personnel Psychology, 634, 937-963.

Wan, T. (2002). Evidence-based health care management: Multivariate modeling approaches. Netherlands: Springer.

Wickenberg, J., \& Kylen, S. (2004). How frequent is organizational behavior? Swedish: Felix.

$\mathrm{Wu}, \mathrm{Y}$. (2011). Job stress and job performance among employees in the Taiwanese finance sector: The role of emotional intelligence. Social Behavior and Personality, 391, 21-32.

Yozgat, U., Yurtkoru, S., \& Bilginoğlu, E. (2013). Job stress and job performance among employees in public sector in Istanbul: Examining the moderating role of emotional intelligence. Procedia - Social and Behavioral Sciences, 75, 518-524. 